\title{
PENERAPAN MODEL PEMBELAJARAN COOPERATIVE SCRIPT UNTUK MENINGKATKAN KEMAMPUAN MEMAHAMI BACAAN DAN PRESTASI BELAJAR PADA MATERI POKOK HIDROLISIS GARAM KELAS XI IPA 2 SEMESTER GENAP SMA NEGERI 1 NGEMPLAK TAHUN PELAJARAN 2016/2017
}

\author{
Berliana Kristaliningtyas, Suryadi Budi Utomo*, dan Sri Yamtinah \\ Program Studi Pendidikan Kimia, FKIP,Universitas Sebelas Maret, Surakarta, Indonesia \\ *keperluan korespondensi, telp: +6281548781644, email: sbukim98@yahoo.com
}

\begin{abstract}
ABSTRAK
Tujuan penelitian ini untuk meningkatkan kemampuan memahami bacaan dan prestasi belajar siswa kelas XI IPA 2 SMA Negeri 1 Ngemplak tahun pelajaran 2016/2017 dengan menerapkan model pembelajaran cooperative script pada materi pokok hidrolisis garam. Metode penelitian yang digunakan adalah penelitian tindakan kelas. Teknik analisis data yang digunakan deskriptif kualitatif. Hasil penelitian menunjukkan bahwa penerapan model pembelajaran cooperative script pada materi hidrolisis garam mampu meningkatkan prestasi belajar siswa kelas XI IPA 2 SMA Negeri 1 Ngemplak. Hasil prestasi belajar kognitif pada siklus I sebesar 39\% dan meningkat pada siklus II menjadi $72,22 \%$. Hasil prestasi belajar afektif pada siklus I sebesar $88,89 \%$ dan meningkat pada siklus II menjadi $100 \%$. Penerapan model pembelajaran cooperative script pada materi hidrolisis garam mampu meningkatkan kemampuan memahami bacaan siswa kelas XI IPA 2 SMA Negeri 1 Ngemplak. Hasil kemampuan memahami bacaan pada siklus I sebesar $85,71 \%$ dan meningkat pada siklus II menjadi $100 \%$.
\end{abstract}

Kata Kunci: penelitiantindakan kelas, Cooperative Script, kemampuan memahami bacaan, prestasi belajar

\section{PENDAHULUAN}

Pembelajaran kimia tidak lepas dari keterkaitan beberapa pihak seperti kompetensi guru, siswa, teknisi laboran, proses belajar mengajar, dan fasilitas. Proses pembelajaran yang baik terjadi apabila adanya interaksi yang baik antara guru dan siswa. Guru harus memiliki kreativitas dalam pembelajaran agar siswa terlibat aktif dalam proses pembelajaran. Namun pada kenyataannya proses pembelajaran kimia di sekolah umumnya masih berlangsung secara konvensional. Pembelajaran masih berpusat pada guru (teacher centered) bukan berpusat pada siswa (student centered). Siswa hanya mendengarkan ceramah dan mencatat. Guru lebih memilih untuk melakukan pembelajaran secara konvensional karena sudah terbiasa dan lebih simpel.
Padahal materi kimia bersifat abstrak dan akan sulit dipahami jika hanya dijelaskan melalui ceramah saja.

Selain itu proses pembelajaran kimia tidak lepas dari fenomenafenomena kimia. Fenomena kimia dijelaskan dalam tiga level representasi yaitu makroskopis, mikroskopis, dan simbolik [1]. Hal tersebut penting diperhatikan oleh guru dalam pembelajaran kimia. Level makroskopis menjelaskan fenomena kimia yang terjadi dalam kehidupan sehari-hari dan dapat dilihat oleh kasat mata, seperti perubahan warna, timbulnya gas. Level mikroskopis menjelaskan kimia secara abstrak seperti atom-atom, molekulmolekul. Sedangkan pada level simbolik menjelaskan makroskopis dengan menggunakan persamaan kimia, persamaan matematika, dan analogi-analogi. Namun 
dalam kenyataannya proses pembelajaran kimia masih membatasi pada level makroskopis dan simbolik. Padahal ilmu kimia sendiri sebagian besar konsepnya memiliki sifat abstrak. Selain itu perhitungan dalam kimia juga kompleks, bahasa yang digunakan juga tidak lazim. Hal inilah yang menyebabkan banyak siswa yang mengalami kesulitan mempelajari mata pelajaran kimia. Hal tersebut juga dialami oleh siswa-siswi di SMA N 1 Ngemplak.

SMA Negeri 1 Ngemplak merupakan salah satu sekolah yang berada di kabupaten Boyolali. Sekolah ini berada di perbatasan antara kota Solo dengan kabupaten Boyolali. Sekolah tersebut bukan sekolah favorit di kabupaten Boyolali. SMA Negeri 1 Ngemplak merupakan satu-satunya sekolah di Indonesia yang telah menerapkan gerakan literasi. Gerakan literasi sekolah ini merupakan gerakan membaca buku selama $10-15$ menit sebelum memulai pelajaran. Semua siswa diminta untuk berbaris di lapangan dengan membawa buku bacaan, buku jurnal, dan alat tulis. Gerakan literasi ini dilakukan setelah siswa melaksanakan apel pagi. Setelah membaca bacaan siswa diminta untuk merangkum bacaan tersebut dan mencatatnya dalam jurnal harian. Buku yang dibaca siswa sebagian besar masih berupa novel. Berdasarkan observasi kemampuan memahami bacaan siswa untuk buku fiksi sudah cukup bagus akan tetapi berbeda untuk buku non-fiksi atau buku pelajaran.

Beberapa materi kimia memerlukan kemampuan memahami bacaan. Salah satu materinya adalah hidrolisis garam. Hidrolisis garam merupakan materi yang menggunakan pemahaman konsep di awal materi baru siswa dapat memahami hitungan. Beberapa siswa mengalami kesulitan dalam soal - soal teori karena kurangnya pemahaman dalam membaca. Siswa kesulitan dalam membedakan sifat larutan garam. Kurangnya pemahaman dalam membaca juga membuat siswa bingung dalam menerapkan rumus-rumus karena kurang paham konsep di awal materi. Selain itu siswa juga sering kesulitan membedakan antara larutan penyangga dengan hidrolisis garam. Oleh karena itu, pada materi hidrolisis garam diperlukan kemampuan memahami bacaan materi. Kemampuan memahami bacaan merupakan kemampuan seseorang dalam memahami kata per kata dalam kalimat. Pemahaman materi melalui membaca dapat berpengaruh terhadap prestasi belajar.

Hal ini sesuai dengan penelitian bahwa kemampuan memahami bacaan berpengaruh terhadap prestasi belajar siswa pada nilai toefl [2]. Penelitian lain juga menunjukan adanya sumbangan relatif prestasi belajar untuk variabel kemampuan membaca [3]. Kemampuan memahami bacaan juga memiliki hubungan dengan prestasi belajar siswa [4]. Ada beberapa faktor yang memengaruhi prestasi belajar yaitu ada faktor internal dan eksternal [5]. Faktor internal berasal dari dalam individu seperti keadaan jasamani, psikologis. Faktor eksternal berasal dari luar individu seperti keluarga, sekolah, dan masyarakat.

Peningkatan prestasi belajar dan kemampuan memahami bacaan dapat dilakukan dengan model pembelajaran cooperative script. Hal ini telah diteliti bahwa penerapan model pembelajaran cooperative script dapat meningkatkan hasil belajar [6]. Model pembelajaran cooperative script dapat diterapkan pada pembelajaran yang bersifat kognitif [7]. Setiap setiap peserta didik nantinya diberikan materi ajar secara lengkap, dibagi berpasang-pasangan dan masingmasing dari mereka bergantian secara lisan mengintisarikan materi yang telah diberikan. Lalu pasangan lainnya mengoreksi apakah benar pernyataan yang diungkapkan oleh temannya tersebut atau tidak. Model pembelajaran cooperative script ini diadaptasikan dengan kemampuan siswa dalam proses pembelajarannya serta membangun kemampuan siswa untuk membaca dan menyusun rangkuman berdasarkan materi yang dibacanya, sehingga dapat meningkatkan pemahaman konsep siswa terhadap materi yang diajarkan [8]. Kemampuan memahami bacaan 
akan tampak saat siswa dapat menentukan ide pokok dalam bacaan setelah membaca. Model pembelajaran cooperative script dapat meningkatkan keefektifan dalam memahami bacaan [9]. Sehingga diharapkan dengan menerapkan model pembelajaran ini dapat meningkatkan kemampuan memahami bacaan siswa.

\section{METODE PENELITIAN}

Penelitian ini merupakan Penelitian Tindakan Kelas (PTK) yang dilaksanakan dalam dua siklus. Setiap siklusnya terdapat empat tahapan, yaitu perencanaan, pelaksanaan, observasi, dan refleksi.Subjek penelitian adalah siswa kelas XI IPA 2 SMA Negeri 1 Ngemplak tahun pelajaran 2016/2017.

Data yang dikumpulkan meliputi data tentang keadaan siswa yang berupa data kualitatif dan kuantitatif. Data kualitatif diperoleh dari hasil observasi, angket sikap, dan wawancara. Data kuantitatif didapat dari hasil penilaian prestasi belajar materi pokok hidrolisis garam dan kemampuan memahami bacaan pada siklus I maupun siklus II.

Teknik analisis data pada penelitian ini menggunakan analisis deskriptif. Analisis data menggunakan tiga tahap yaitu reduksi data (pengelolaan data), penyajian data (mengorganisasikan data kedalam suatu bentuk tertentu sehingga datanya terlihat lebih utuh), dan triangulasi atau pemeriksaan keabsahan data dengan memanfaatkan sesuatu yang lain diluar data tersebut sebagai pembanding data.

\section{HASIL DAN PEMBAHASAN}

Penelitian tindakan kelas ini bertujuan untuk meningkatkan kemampuan memahami bacaan dan prestasi belajar siswa kelas XI IPA 2 SMA N 1 Ngemplak pada materi hidrolisis garam dengan menerapkan model pembelajaran Cooperative Script. Kemampuan Memahami bacaan Siswa meliputi aspek literal, reorganisasi, dan inferensial. Prestasi belajar yang diukur meliputi aspek sikap dan pengetahuan.
Penelitian ini dilakukan dalam 2 siklus yaitu siklus I dan siklus II. Masingmasing siklus terdiri dari tahap perencanaan, tahap pelaksanaan tindakan, tahap pengamatan dan tahap refleksi. Proses pembelajaran menggunakan model Cooperative Script dilakukan berpasangan untuk memberikan kesempatan kepada siswa untuk aktif dalam proses pembelajaran.

\section{Siklus I}

\section{a. Perencanaan}

Pada tahap perencanaan siklus I dilakukan penyusunan silabus, RPP, modul, instrumen penilaian kemampuan memahami bacaan, serta instrumen prestasi belajar. Berdasarkan data silabus diketahui bahwa materi hidrolisis memiliki alokasi waktu 7 jam pelajaran (7jp). Perincian pembelajaran pada siklus I yaitu 5jp (5 x 45 menit) untuk penyampaian materi dan 2jp (2 x 45 menit) untuk evaluasi siklus I.

\section{b. Pelaksanaan}

Tahap pelaksanaan pada siklus I terdiri dari 3 kali pertemuan, dengan 2 kali pertemuan untuk penyampaian materi dan 1 kali pertemuan untuk evaluasi siklus I. Pada pertemuan awal dilakukan penyampaian materi sifat sifat larutan garam, jenis hidrolisis pada larutan garam, dan reaksi hidrolisis pada larutan garam. Model pembelajaran yang digunakan adalah cooperative script. pembelajaran ini diawali dengan apersepsi dan menjelaskan tujuan serta model pembelajaran yang akan dilakukan hari ini, lalu guru menjelaskan materi yang akan dipelajari secara singkat dan memberikan modul hidrolisis kepada siswa. Para siswa diminta untuk membaca materi pada modul. Kemudian siswa merangkum materi yang sudah dibaca dan menyampaikan materi secara berpasangan. Lalu guru memberikan soal - soal sebagai latihan. Setelah selesai, guru bersama siswa dengan siswa menyimpulkan materi yang sudah dipelajari.

Pertemuan kedua sama dengan pertemuan pertama. Siswa membaca 
sub materi menghitung $\mathrm{pH}$ larutan garam kemudian merangkum dan menyampaikan rangkuman berpasangan. Pertemuan terakhir, guru melakukan evaluasi I meliputi penilaian aspek pengetahuan dan kemampuan memahami bacaan.

\section{c. Pengamatan}

Hasil penilaian observasi dan analisis hasil tes pada siklus I dapat dibuat dalam beberapa kategori-kategori. Hasil penilaian sikap siswa dapat dibuat kategori seperti pada Gambar 1.

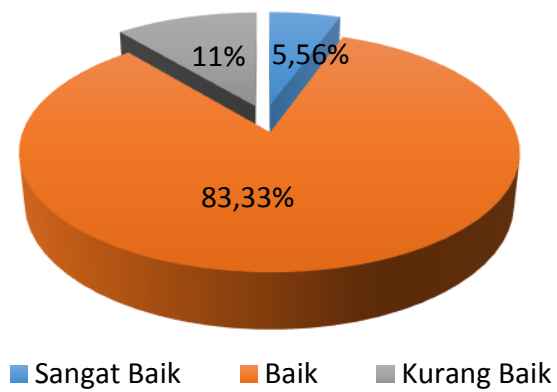

Gambar 1. Ketercapaian Aspek Sikap Siswa Siklus I

Gambar 1 menunjukkan jika secara umum capaian aspek sikap siswa sudah cukup baik hal itu ditunjukan dari jumlah siswa sangat baik dan baik melampaui target siklus I sebesar 70\%. Namun penilaian tetap dilanjutkan pada siklus II untuk mengetahui peningkatannya.

Hasil penilaian aspek pengetahuan siklus I bisa dilihat pada Gambar 2. Hasil siklus I terdapat dua indikator yang belum tuntas yaitu menentukan sifat - sifat larutan garam, menghitung $\mathrm{pH}$ larutan garam sehingga perlu dilanjutkan ke siklus II. Indikator menentukan sifat sifat larutan garam ketuntasannya sebesar $67 \%$. Lalu ketuntasan indikator menghitung $\mathrm{pH}$ larutan garam sebesar $52 \%$. Hal ini belum mencapai target yaitu $70 \%$. Gambar 2 menunjukkan bahwa siswa yang nilai yang tuntas masih di bawah target siklus I yaitu $70 \%$. Siswa yang tuntas sebanyak 14 orang atau $39 \%$. Siswa yang tidak tuntas sebanyak 22 orang atau $61 \%$.

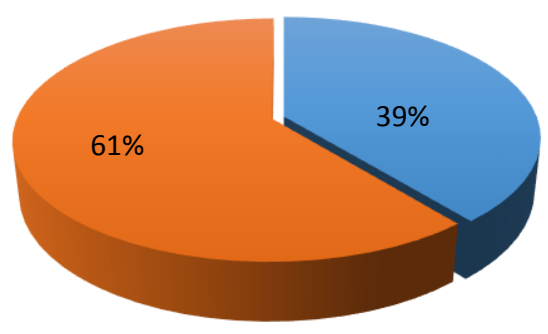

Tuntas Tidak Tuntas

Gambar 2. Ketercapaian Aspek Pengetahuan Siklus I

Hasil penilaian aspek kemampuan memahami bacaan bisa dilihat pada Gambar 3.

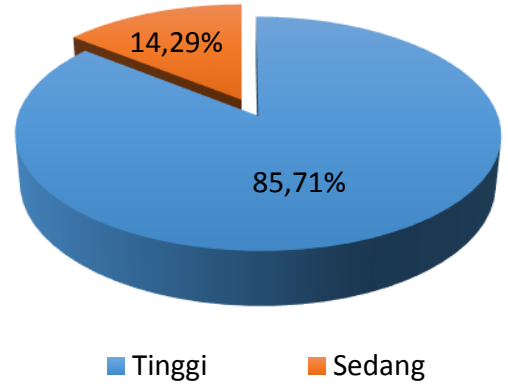

Gambar 3. Ketercapaian Aspek Kemampuan Memahami bacaan Siklus I

Gambar 3 menunjukkan bahwa aspek kemampuan memahami bacaan sudah mencapai target $70 \%$ pada siklus I. Siswa yang memiliki kategori tinggi sebsar $85,71 \%$ sedangkan yang sedang sebesar 14,29\%. Aspek kemampuan memahami bacaan tetap diuji pada siklus II untuk mengetahui peningkatannya.

\section{d. Refleksi}

Hasil pengamatan yang dilakukan menunjukkan masih terdapat aspek yang belum mencapai target yaitu aspek pengetahuan. Aspek sikap dan kemampuan memahami bacaan tetap diujikan di siklus II untuk mengetahui peningkatannya. Oleh karena itu, perlu dilaksanakan siklus II yang diharapkan dapat mencapai target yang sudah ditentukan yaitu $70 \%$. 


\section{Siklus II}

\section{a. Perencanaan}

Pada pelaksanaan siklus II ini lebih difokuskan untuk perbaikan terhadap kendala-kendala yang muncul pada siklus I. Materi yang diberikan juga fokus pada indikator-indikator yang belum mencapai ketuntasan yaitu menentukan tetapan hidrolisis garam dan menentukan $\mathrm{pH}$ larutan garam. Pemberian evaluasi juga terbatas pada soal dengan indikator-indikator yang belum tuntas saja. Guru lebih memfokuskan pada siswa yang hasil evaluasi siklus I mendapatkan nilai yang tergolong rendah dibandingkan teman-temannya untuk perbaikan pada siklus II. Guru memberikan latihan soal yang lebih bervariasi di siklus II.

\section{b. Pelaksanaan}

Siklus II ini dilaksanakan dalam 2 kali pertemuan, yaitu 1 kali pertemuan untuk penyampaian materi dan 1 kali pertemuan untuk evaluasi siklus II.

Pada pertemuan pertama, guru menjelaskan kepada siswa bahwa pembelajaran ini lebih difokuskan kepada materi yang belum dipahami pada siklus I yaitu pada indikator menentukan sifat larutan garam dan menghitung $\mathrm{pH}$ larutan garam. Siswa membaca sub materi, merangkum, dan menyampaikan isi rangkuman berpasangan. Lalu memberikan soal latihan. Guru dan siswa bersama membuat kesimpulan di akhir pembelajaran.

Pada pertemuan kedua atau pertemuan terakhir dilaksanakan evaluasi siklus II yang terdiri atas tes aspek pengetahuan berupa 12 soal objektif dan sisa waktunya digunakan untuk mengerjakan soal kemampuan memahami bacaan.

\section{c. Pengamatan}

Hasil observasi dan analisis tes yang sudah dilakukan pada siklus II dapat dilihat dari hasil pada masingmasing aspek, yaitu aspek sikap, pengetahuan, dan kemampuan memahami bacaan. Hasil observasi dan analisis angket siswa dapat dilihat pada
Gambar 5. Hasil yang disajikan pada Gambar 5 menunjukkan capaian siswa yang berkategori baik dan sangat baik sudah melampaui target yang direncanakan dan semua indikator juga sudah mencapai target sebesar $70 \%$, sehingga, penilaian aspek sikap dilakukan sampai siklus II ini. Penilaian aspek sikap siklus II mengalami peningkatan dibandingkan dengan siklus I. Hasil penilaian menunjukkan tidak ada siswa yang berkategori kurang baik. Semua siwa berkategori sangat baik dan baik.

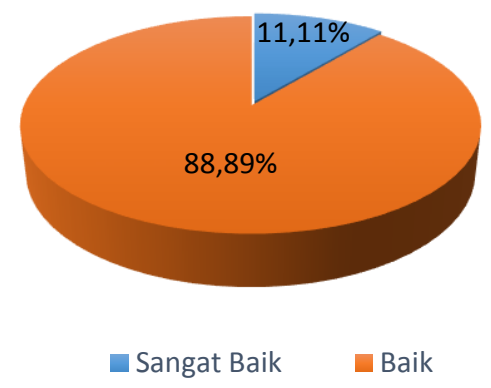

Gambar 4. Ketercapaian Aspek Sikap Siswa Siklus II

Hasil tes aspek pengetahuan siklus II dapat dilihat pada Gambar 6 .

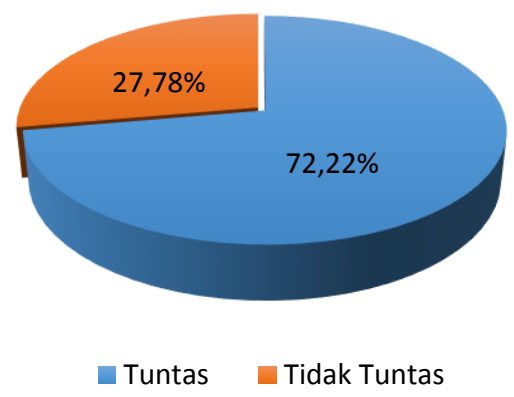

Gambar 5. Ketercapaian Aspek

Pengetahuan Siklus II

Jumlah capaian aspek pengetahuan siklus ini sebesar $72,22 \%$, hasil ini sudah melampaui target sebesar $70 \%$. Semua indikator pada siklus ini juga sudah mencapai target yang sudah direncanakan sehingga penilaian aspek pengetahuan siswa diakhiri pada siklus II.

Hasil tes kemampuan memahami bacaan siklus II dapat dilihat pada Gambar 6. Gambar 6 menunjukkan capaian aspek kemampuan memahami 
bacaan siswa sudah cukup baik hal itu ditunjukan dari jumlah siswa tuntas yang sudah mencapai target sebesar $70 \%$. Semua indikator pada aspek kemampuan memahami bacaan juga sudah mencapai target sehingga penilaian aspek keaktifan diakhiri pada siklus II.

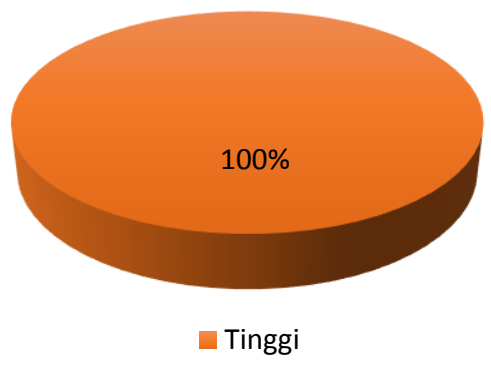

Gambar 6. Ketercapaian Aspek Kemampuan Memahami bacaan Siklus II

\section{d. Refleksi}

Berdasarkan data yang diperoleh pada siklus II, terlihat semua aspek meliputi aspek pengetahuan, sikap dan kemampuan memahami bacaan mengalami peningkatan capaian dan sudah melampaui target sehingga penelitian di akhiri pada siklus II.

\section{Perbandingan Hasil 2 Siklus}

Berdasarkan hasil observasi, angket, tes dan wawancara yang telah dilakukan selama proses pembelajaran dengan model cooperative script diperoleh data bahwa model tersebut dapat meningkatkan kemampuan memahami bacaan dan prestasi belajar pada materi hidrolisis garam. Kemampuan memahami bacaan dinilai dari tes kemampuan memahami bacaan yang diberikan pada akhir siklus. Data ketercapaian kemampuan memahami bacaan siswa siklus I dan II disajikan pada Gambar 7.

Berdasarkan Gambar 7, dapat dilihat bahwa kemampuan memahami bacaan mengalami peningkatan dari siklus I ke siklus II. Hal ini disebabkan oleh dengan penggunaan model cooperative script membuat siswa mempunyai kesempatan yang lebih banyak untuk membaca. Siswa juga menjadi lebih aktif untuk membaca, merangkum, dan menyampaiakan isi rangkuman. Melalui model cooperative script siswa dituntun untuk mengobservasi sendiri mengenai materi yang dipelajari, sehingga siswa akan lebih lama mengingat konsep yang ada.

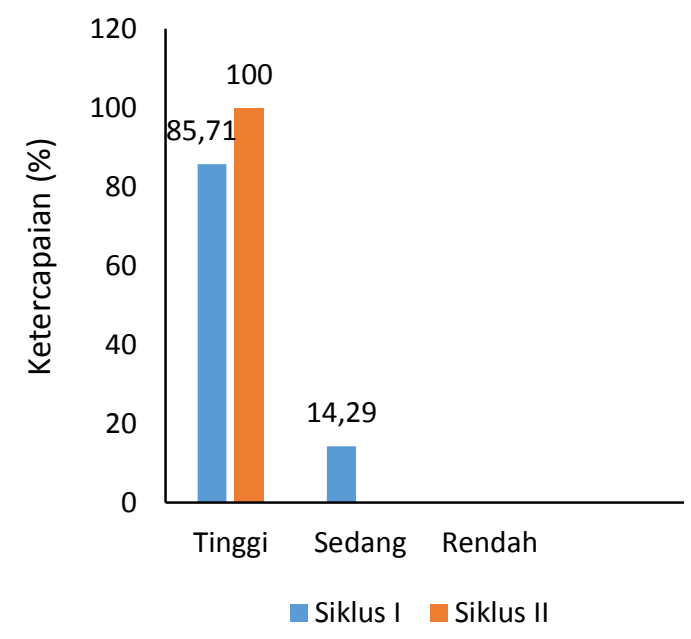

Gambar 7. Diagram Perbandingan Aspek Kemampuan Memahami bacaan Siklus I dan Siklus II

Aspek berikutnya yang dinilai dalam penelitian ini yaitu sikap. Aspek sikap memiliki target sebesar $70 \%$ siswa tuntas. Jenjang sikap siswa yang diamati yaitu sikap, minat, nilai, konsep diri, dan moral. Cara penilaian aspek sikap berdasarkan Kurikulum Tingkat Satuan Pendidikan (KTSP), yaitu dengan menggunakan rata - rata. Kategori ketuntasan sikap terdiri dari sikap sangat baik dan sikap baik.

Pada siklus I pencapaian aspek sikap kategori baik sebesar 88,89\%. Hasil ini sudah memenuhi target yang telah ditentukan, namun pada pelaksanaan siklus II tetap dilakukan penilaian aspek sikap dikarenakan untuk mengetahui peningkatannya. $\mathrm{Hal}$ ini dilakukan dengan tujuan untuk mengetahui apakah sikap siswa mengalami peningkatan setelah adanya perbaikan pada proses pembelajaran. Hasil data yang diperoleh pada siklus II mengalami peningkatan menjadi $100 \%$ pada kategori baik dan sangat baik. Hasil ini telah mencapai target dan mengalami peningkatan sebesar $11,11 \%$. Oleh karena itu, penilaian aspek afektif tidak 
dilanjutkan ke siklus berikutnya. Berikut dapat dilihat perbandingan kategori aspek sikap pada Gambar 8.

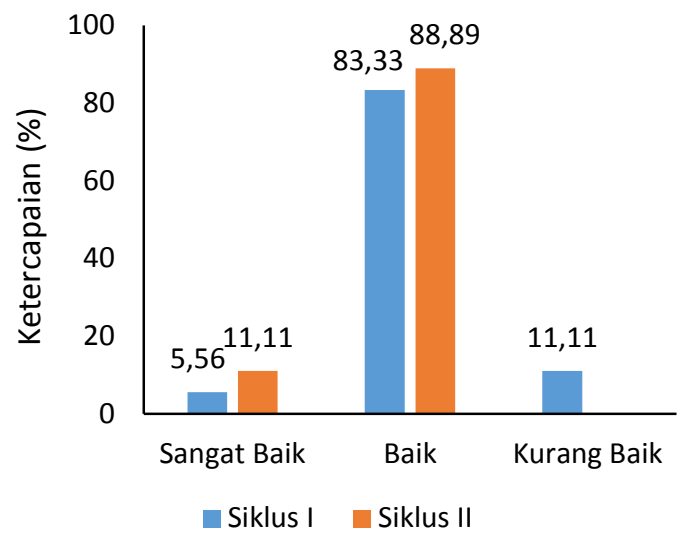

Gambar 8. Diagram Perbandingan Aspek Sikap Siklus I dan Siklus II

Variabel selanjutnya yang diteliti adalah prestasi belajar aspek kognitif. Pengamatan awal atau prasiklus pada penelitian ini dilakukan pada nilai ulangan harian materi hidrolisis pada tahun ajaran 2014/2015 dan 2015/2016. Berdasarkan hasil kajian nilai tersebut diketahui bahwa ketuntasan materi hidrolisis belum mencapai $70 \%$ siswa tuntas. Target ketuntasan aspek pengetahuan pada penelitian ini yaitu $70 \%$. Pada siklus I terdapat 4 indikator yang harus dicapai, akan tetapi hasil dari siklus I menunjukkan bahwa masih ada 2 indikator yang belum tercapai dan ketuntasan siswa hanya mencapai 39\%. Presentase ketuntasan aspek pengetahuan siklus I dan siklus II ditunjukkan pada Gambar 9.

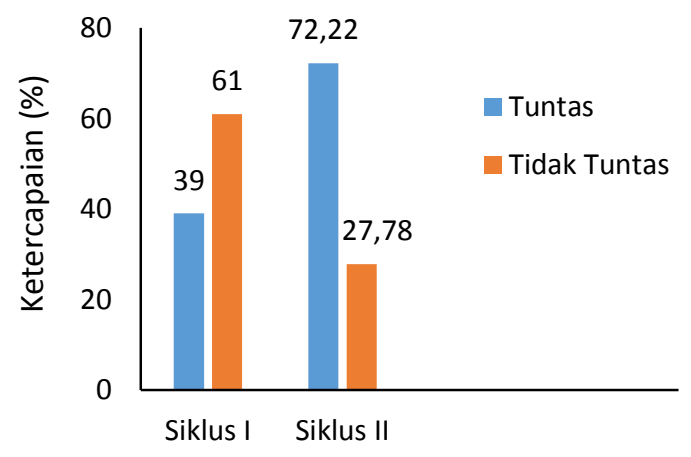

Gambar 9. Diagram Perbandingan Aspek Pengetahuan Siklus I dan Siklus II
Pada siklus I diperoleh ketuntasan aspek pengetahuan sebesar 39\% atau sebanyak 14 siswa tuntas. Belum tuntasnya target pada siklus I ini dapat disebabkan karena siswa belum terbiasa dengan penggunaan model pembelajaran cooperative script, oleh karena itu pembelajaran dilanjutkan ke siklus II untuk meningkatkan hasil aspek pengetahuan.

Hasil tes siklus II menunjukkan $72,22 \%$ atau sebanyak 26 siswa telah mencapai kriteria ketuntasan minimum. Penggunaan model pembelajaran cooperative script dapat meningkatkan prestasi belajar kimia pada siswa. Hal ini berarti hasil aspek pengetahuan pada siklus II telah mencapai target. Kenaikan aspek pengetahuan dari prasiklus ke siklus I dan siklus II dapat disebabkan oleh beberapa faktor, salah satunya yaitu adanya kegiatan membaca. Model pembelajaran cooperative script melatih peserta didik untuk menemukan sendiri ilmu pengetahuan yang ingin ditransfer oleh pendidik. Proses penemuan ilmu pengetahuan ini melalui membaca, merangkum, dan menyampaikan rangkuman yang membuat peserta didik lebih berkesan. Peserta didik diharapkan dapat lebih mudah dalam memahami materi sehingga proses pembelajaran dapat berlangsung lebih menyenangkan.

Hasil penilaian yang diperoleh pada siklus II menunjukkan bahwa penelitian tindakan kelas ini berhasil karena semua aspek yang diukur telah mencapai target yang ditentukan. Peningkatan hasil dari siklus I ke siklus II ini disebabkan oleh: (1) adanya penguatan materi mengenai indikator yang belum tuntas sehingga siswa dapat lebih memperdalam pengetahuannya; (2) Proses penemuan ilmu pengetahuan melalui membaca, merangkum, dan menyampaikan rangkuman membuat peserta didik lebih berkesan terhadap materi; dan (3) pengalaman siswa pada siklus I sehingga pada pembelajaran siklus II siswa sudah tidak bingung dan tidak banyak bertanya mengenai model pembelajaran cooperative script yang digunakan. 
Berdasarkan hasil tersebut, penelitian dengan menggunakan model pembelajaran cooperative script dikatakan berhasil karena pada akhir penelitian semua aspek telah mencapai target yang ditetapkan. Penelitian ini dapat meningkatkan proses belajar siswa yang berupa kemampuan memahami bacaan serta prestasi belajar siswa yang terdiri dari aspek sikap, dan spek pengetahuan.

\section{KESIMPULAN}

Berdasarkan hasil penelitian yang telah dilakukan, maka dapat disimpulkan bahwa penerapan model pembelajaran cooperative script pada materi hidrolisis garam kelas XI IPA 2 SMA Negeri 1 Ngemplak Tahun Pelajaran 2016/2017 dapat meningkatkan kemampuan memahami bacaan dan prestasi belajar siswa. Persentase ketercapaian kemampuan memahami bacaan siswa pada siklus I sebesar $85,71 \%$ menjadi $100 \%$ pada siklus II. Peningkatan prestasi belajar siswa juga terlihat dari hasil prestasi belajar aspek sikap 88,89\%. meningkat menjadi 100\% pada siklus II. Lalu aspek pengetahuan pada siklus I $39 \%$ meningkat menjadi $72,22 \%$.

\section{UCAPAN TERIMA KASIH}

Penelitian ini dapat terselenggara dengan baik karena bantuan dari berbagai pihak. Oleh karena itu penulis ingin mengucapkan terimakasih kepada Kepala SMA Negeri 1 Ngemplak, Drs. Sunarno, M.Pd. atas izin yang diberikan kepada penulis untuk melakukan penelitian, dan kepada guru kimia kelas XI S. Kristiyanto, S.Pd. yang telah memberikan izin untuk menggunakan kelas XI IPA 2 sebagai kelas penelitian.

\section{DAFTAR RUJUKAN}

[1] Barke, H.-D., Hazari, A., \& Yitbarek, S. (2008). Misconceptions in Chemistry. Berlin: Springer.

[2] Ali, H. (2012). International Journal of Basic and Applied Science, 1(1), 47-52.
[3] Daro, F., Yamtinah, S., \& Nurhayati, N. D. (2013). Pendidikan Kimia (JPK), 2(3), 139-145.

[4] Javed, M. (2015). International Journal of Instruction, 8(2), 140-154. https://doi.org/10.12973/iji.2015.821 1a

[5] Slameto. (2010). Belajar dan Faktorfaktor yang Mempengaruhinya. Jakarta: Rineka Cipta.

[6] Maksum, A., \& Sedyawati, S. M. R. (2013). Inovasi Pendidikan, 7(1), 1072-1082.

[7] Meilani, R., \& Sutarni, N. (2016). Pendidikan Manajemen Perkantoran, 1(1), 186-197.

[8] Natalina, M., \& Srini, N. (2013). Biogenesis, 10(1), 43-52.

[9] Oktaviyani, V. (2013). Skripsi, Hlm 66. Universitas Negeri Yogyakarta 